\title{
Bioprospecção de rizobactérias promotoras de crescimento em Brachiaria brizantha
}

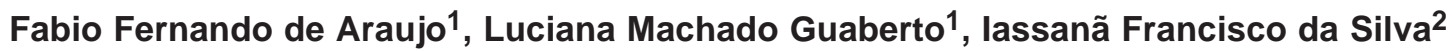 \\ ${ }^{1}$ Faculdade de Ciências Agrárias - UNOESTE, Presidente Prudente, SP. \\ 2 Programa de Pós-Graduação em Produção Vegetal - Agronomia da FCA/UNOESTE.
}

RESUMO - Objetivou-se selecionar e caracterizar bactérias do gênero Bacillus em rizosfera de Brachiaria brizantha como promotoras de crescimento de plantas e correlacionar os diferentes critérios de seleção das bactérias utilizados em laboratório e casa-de-vegetação. Após coleta de amostras de plantas em três municípios da região oeste de São Paulo, foram realizados o isolamento de bactérias da rizosfera e posterior caracterização fenotípica quanto ao potencial de colonização de raízes de braquiária, antagonismo a fungos fitopatogênicos, produção de auxinas, fosfatases e proteases, além da caracterização genotípica utilizando a técnica de PCR-RAPD. Como avaliação final dos isolados bacterianos foi realizado experimento em casa-de-vegetação com inoculação de sementes e cultivo de Braquiaria brizantha com efetivação de três cortes, durante 180 dias. O experimento foi distribuído em delineamento inteiramente casualizado com quatro repetições. Dos 45 isolados de Bacillus sp. avaliados, sete foram competentes para colonização radicular e três (1A, 2B e 6A) foram capazes de promover o crescimento de Brachiaria brizantha, na média de três cortes efetuados na cultura. A avaliação da produção de auxinas e fosfatases foi relevante no protocolo de seleção dos isolados de Bacillus sp. como promotores de crescimento de plantas. A produção de proteases foi detectada em todos os isolados avaliados, mas não houve correlação desta característica com o crescimento das plantas.

Palavras-chave: atividade enzimática, Bacillus sp., pastagens, rizosfera

\section{Bioprospection of plant growth promoter rhizobacteria in Brachiaria brizantha}

\begin{abstract}
This study proposed to select and characterize bacteria of the genus Bacillus on rhizosphere of Brachiaria brizantha as plant growth promoters and to correlate the different selection criteria of the bacteria utilized in laboratories and greenhouse. After collecting samples of plants in three municipalities of Sao Paulo, bacteria were isolated from the rhizosphere and subsequent phenotypic characterization was carried out, regarding the potential for colonization of the roots of pasture, antagonism to pathogenic fungi, production of auxins, phosphatases and proteases in addition to the genotypic characterization using PCR-RAPD. As final evaluation of Bacillus sp. isolates, a greenhouse experiment was performed with seed inoculation and cultivation of Brachiaria brizantha with three harvests, during 180 days. The experiment was distributed in completely randomized design with four replications. Of the 45 isolates of Bacillus sp. evaluated, seven were able to root colonization and three (1 A, 2B and $6 \mathrm{~A}$ ) were able to promote the growth of Brachiaria brizantha, on the average of three harvests. The evaluation of auxin and phosphatase production was important in the selection protocol of Bacillus sp. to promote plant growth. Protease production was detected in all isolates, but there was no correlation of this characteristic with plant growth.
\end{abstract}

Key Words: Bacillus sp., enzymatic activity, pastures, rhizosphere

\section{Introdução}

As pastagens são o principal componente das dietas de ruminantes e a fonte de alimentação mais econômica nos sistemas pecuários (Skonieski et al., 2011). Com isso, torna-se prioridade aumentar a utilização das forragens via otimização do consumo e da disponibilidade de seus nutrientes (Gomes Júnior et al., 2002). Neste sentido, as novas tecnologias que visam o aumento de rendimento das pastagens com baixo custo são essenciais para adoção no manejo dessas culturas (Itzigsohn et al., 2000).

As rizobactérias que habitam o solo e são promotoras do crescimento de plantas (RPCPs) são com frequência isoladas da rizosfera de diversas plantas cultivadas. Entre os gêneros mais estudados, destacam-se: Bacillus, Pseudomonas, Azospirillum e Rhizobium. Os efeitos desses microrganismos sobre o desenvolvimento das plantas são amplos e incluem os efeitos benéficos na germinação de 
sementes, emergência de plântulas e crescimento das plantas (Figueiredo et al., 2010).

A influência das rizobactérias no crescimento das plantas tem sido atribuída a efeitos indiretos associados ao controle biológico de patógenos secundários (Araujo et al., 2005). No entanto, em alguns trabalhos, a promoção de crescimento de plantas, por rizobactérias, também tem sido relacionada à produção de fitohormônios e enzimas líticas (Vassilev et al., 2006).

Poucos estudos foram conduzidos com a inoculação de sementes de pastagens com rizobactérias promotoras de crescimento, contudo Itzigsohn et al. (2000) mostraram que a inoculação da bactéria diazotrófica Azospirillum spp. em pastagens tem grande potencial para se tornar uma técnica aplicável, principalmente em condições de déficit hídrico e/ou baixa fertilidade. Nestas situações rizobactérias que produzem hormônios podem mudar a morfologia radiculare aumentar sua biomassa, ampliando com isso a capacidade de exploração do solo (Malik et al., 1997). Araujo (2008), em estudo de inoculação de Bacillus subtilis em diferentes culturas, demonstrou que a inoculação aumentou significativamente o teor de nitrogênio no tecido foliar de milho, mesmo considerando que a espécie bacteriana introduzida não é diazotrófica, porém já foi caracterizada como produtora de hormônios (Araujo et al., 2005).

Objetivou-se selecionar e caracterizar bactérias do gênero Bacillus em rizosfera de Brachiaria brizantha como promotoras de crescimento de plantas e correlacionar os diferentes critérios de seleção das bactérias utilizados em laboratório e casa-de-vegetação.

\section{Material e Métodos}

O experimento foi conduzido no laboratório de microbiologia e na casa-de-vegetação da Faculdade de Ciências Agrárias da Universidade do Oeste Paulista UNOESTE, em Presidente Prudente, São Paulo, durante os meses de junho de 2009 a fevereiro de 2010. Foram coletadas amostras de Brachiaria brizantha em áreas de pastagens estabelecidas há mais de dois anos em três municípios da região oeste de São Paulo, (Pirapozinho - 22 $2^{\circ} 16^{\prime} 55^{\prime \prime} \mathrm{S}$ $51^{\circ} 29^{\prime} 51^{\prime \prime} \mathrm{W}$; Dumontina - $22^{\circ} 19^{\prime} 00^{\prime \prime} \mathrm{S} 51^{\circ} 40^{\prime} 01^{\prime \prime} \mathrm{W}$ e Tarabai- $\left.22^{\circ} 17^{\prime} 22^{\prime \prime} \mathrm{S} 51^{\circ} 32^{\prime} 08^{\prime \prime}\right)$. A região apresenta-se com altitude média de $450 \mathrm{~m}$ e predominância de solos arenosos. O clima da região é classificado, com base no sistema de Koppen, como Cwa, mesotérmico, de inverno seco, em que a temperatura média do mês mais frio é inferior a $18^{\circ} \mathrm{C}$ e a do mês mais quente ultrapassa $25^{\circ} \mathrm{C}$.

Foram coletadas em cada município 12 amostras de plantas, sendo escolhidas quatro plantas em três áreas diferentes. As plantas foram transportadas para o laboratório, onde as raízes foram separadas da parte aérea para isolamento de bactérias do gênero Bacillus, conforme descrito em Coelho et al. (2007) e Buchanan \& Gibbons (1975). Para isso, as raízes foram lavadas rapidamente em água corrente e, em seguida, com o solo que permaneceu aderido, foram colocadas em erlenmeyers com $100 \mathrm{~mL}$ de solução salina $\left(\mathrm{MgSO}_{4} \quad 7 \mathrm{H}_{2} \mathrm{O} \quad 0,01 \mathrm{M}\right)$ esterilizada previamente. $\mathrm{O}$ conjunto raiz + solo que permaneceu aderido foi considerado ambiente rizosférico. O conjunto foi então submetido a 30 minutos de agitação $\left(120 \mathrm{rpm}, 28^{\circ} \mathrm{C}\right)$ em agitador orbital mecânico. Em seguida, foram realizadas quatro diluições sucessivas a partir da coleta de $1,0 \mathrm{~mL}$ da suspensão do interior do frasco, empregando-se tubos de ensaio com $9 \mathrm{~mL}$ de solução salina estéril e efetivando-se a transferência de $1 \mathrm{~mL}$ de um tubo para o outro. Os tubos foram então submetidos a choque térmico a $80^{\circ} \mathrm{C}$ por vinte minutos, visando selecionar bactérias termoresistentes, critério imprescindível para diferenciar Bacillus spp. dos demais possíveis isolados, devido a presença de esporos de resistência (Bettiol, 1995). Dos tubos da última e penúltima diluição foi retirado $0,1 \mathrm{~mL}$ que foi espalhado na superfície de meio de cultura ágar nutriente $\left(3 \mathrm{~g} \mathrm{~L}^{-1}\right.$ de extrato de levedura, $5 \mathrm{~g} \mathrm{~L}^{-1}$ de peptona e $15 \mathrm{~g} \mathrm{~L}^{-1}$ de ágar), em placas de Petri, que foram posteriormente incubadas em estufa a $28^{\circ} \mathrm{C}$, durante 72 horas. Após isto foram isoladas colônias confirmadas posteriormente como pertencentes ao gênero Bacillus de acordo com Buchanan \& Gibbons (1975). Após caracterização das culturas bacterianas como gram positivas e formadoras de endosporos, visualizados por microscopia de contraste de fase (1000x), chegou-se ao total de 45 isolados de Bacillus sp.

$\mathrm{Na}$ etapa posterior, foi verificada a capacidade de colonização das raízes de Brachiaria, critério imprescindível para recomendação das bactérias como promotoras de crescimento de plantas (Benizri et al., 2001). Para isto foi efetivado o teste de colonização de raízes em tubos com agar-água, conforme descrito por Romeiro (2007). Sementes de braquiaria foram desinfestadas previamente e em seguida transferidas para tubos de ensaio ( 2 sementes por tubo), contendo meio agar-água ( $0,6 \%$ de Agar). Os tubos foram mantidos em câmara de crescimento, sem luz, durante 3 a 4 dias até a emissão da radícula. Após isto introduziu-se 0,1 $\mathrm{mL}$ de suspensão bacteriana próximo à radícula. Os tubos de ensaio foram mantidos sob a luminosidade e temperatura ambiente, sendo observados diariamente para avaliação visual da colonização radicular, a qual é representada por uma zona túrbida, de aspecto leitoso, delgada, em volta das raízes (Romeiro, 2007). Nesta etapa foram selecionados apenas sete isolados bacterianos que confirmaram a 
colonização radicular de Brachiaria, de acordo com o critério estabelecido, o qual é importante para o estabelecimento da bactéria na rizosfera (Benizri et al., 2001).

Como forma de caracterização fenotípica dos sete isolados selecionados quanto a atividades bioquímica de importância agrícola, foram realizados ensaios em laboratório quanto ao antagonismo a fungos fitopatogênicos, produção de auxinas, fosfatases e proteases. Inicialmente, para avaliar o antagonismo, foi utilizado o método de pareamento em placas de Petri contendo o meio Batata Dextrose Agar (BDA) segundo metodologia descrita por Araujo et al. (2005). Foram utilizados os seguintes fungos fitopatogênicos: Aspergillus niger (Isolado LMU 12) isolado originalmente de sementes de milho e Fusarium oxysporum f. sp. vasinfectum raça 1 (Isolado LFB 37), cedido pelo Dr. Nilton L. Souza, UNESP, Botucatu, SP, ambos depositados na coleção do laboratório de fitopatologia da Unoeste, São Paulo. Os fungos foram multiplicados em meio de cultura agar batata durante sete dias. Após este período, discos com diâmetro de $5 \mathrm{~mm}$ contendo o micélio do fungo foram introduzidos em quatro pontos equidistantes em placa de Petri, com meio BDA, 24 horas antes da inoculação do isolado de Bacillus no centro da placa. Cada isolado foi avaliado em triplicata. As placas foram incubadas em estufa a $28^{\circ} \mathrm{C}$ por sete dias. Após este período, foi observada a formação ou não de zona de inibição entre o isolado bacteriano e o fungo fitopatogênico.

A produção de auxinas pelos isolados bacterianos baseou-se na avaliação de AIA (ácido indol-acético) pelo método colorimétrico (Radwan et al., 2005), onde inicialmente as bactérias foram cultivadas em erlenmeyers com $50 \mathrm{~mL}$ de meio líquido TSB (Trypticase Soy Broth, Oxoid ${ }^{\mathbb{R}}$ ) suplementado com $10 \mathrm{~g} \mathrm{~L}^{-1}$ de dextrose, $5 \mathrm{~g} \mathrm{~L}^{-1}$ de extrato de levedura e $5 \mathrm{mM}$ de L-triptófano (1000 ug $\left.\mathrm{mL}^{-1}\right)$. O meio de cultura após inoculação com os isolados, em triplicata, foi mantido a $28^{\circ} \mathrm{C}$ no escuro, sob agitação constante ( $120 \mathrm{rpm}$ ), durante 24 horas. Após este período, foram coletados $10 \mathrm{~mL}$ da suspensão bacteriana e realizada centrifugação a $10.000 \mathrm{~g}$ durante 10 minutos, para obtenção do sobrenadante. A quantidade de AIA por $\mathrm{mL}$ foi estimada pela mistura de $5 \mathrm{~mL}$ de reagente de Salkowski(Ehmann, 1977) com $1 \mathrm{~mL}$ do sobrenadante de cada isolado e após 30 minutos foi realizada a leitura da absorbância $(500 \mathrm{~nm})$. A concentração final de AIA no meio foi determinada utilizando-se uma curva padrão. A produção de fosfatases foi quantificada pela técnica descrita por Romeiro (2007), iniciada pela introdução de porção de cada isolado bacteriano em $25 \mathrm{~mL}$ de caldo nutriente $\left(5 \mathrm{~g} \mathrm{~L}^{-1}\right.$ de peptona e $3 \mathrm{~g} \mathrm{~L}^{-1}$ de extrato de levedura) acondicionado em erlenmeyers que ficaram sob agitação $\left(150 \mathrm{rpm}, 28^{\circ} \mathrm{C}\right)$, durante 24 horas. Após este período, foi coletado em tubo de ensaio $1,5 \mathrm{~mL}$ da suspensão bacteriana para centrifugação(10.000 rpm por 20 minutos). Do sobrenadante foi coletado $0,5 \mathrm{~mL}$, que foi adicionado a um tubo de ensaio contendo $2,0 \mathrm{~mL}$ dep-nitrofenilfosfato $(0,5 \mathrm{mM})$ para avaliação da atividade enzimática. A mistura foi mantida em banho-maria a $37^{\circ} \mathrm{C}$ por 3 horas e adicionada de $2,5 \mathrm{~mL}$ de $\mathrm{NaOH} 1 \mathrm{M}$. A atividade da fosfatase foi então expressa pela leitura de absorbância (410 nm) na suspensão, onde a coloração amarela indica a formação do paranitrofenol e liberação do fosfato.

A análise da produção de proteases extracelulares pelos isolados foi realizada por método semiquantitativo descrito por Thiago \& Silva (2007). Com auxilio de alça de platina, os isolados bacterianos foram introduzidos em dois pontos equidistantes de placa de petri contendo meio de Simmons $\left(0,2 \mathrm{~g} \mathrm{~L}^{-1}\right.$ de $\mathrm{MgSO}_{4} ; 1,0 \mathrm{~g} \mathrm{~L}^{-1} \mathrm{de} \mathrm{NH}_{4} \mathrm{H}_{2} \mathrm{PO}_{4}$; 2,0 $\mathrm{g} \mathrm{L}^{-1}$ de $\mathrm{K}_{2} \mathrm{HPO}_{4} ; 2,0 \mathrm{~g} \mathrm{~L}^{-1}$ de citrato de sódio; 5,0 $\mathrm{g} \mathrm{L}^{-1}$ de $\mathrm{NaCl}$ e $15 \mathrm{~g} \mathrm{~L}^{-1}$ de agar) acrescido de caseína $\left(1,0 \mathrm{~g} \mathrm{~L}^{-1}\right)$, em triplicata. As placas foram incubadas estufa com controle de temperatura e luminosidade por 10 dias a $26^{\circ} \mathrm{C}$. Após este período, adicionou-se nas placas solução de ácido tricloroacético $\left(10 \% \mathrm{v} \mathrm{v}^{-1}\right)$ para revelação dos halos de degradação que indicaria a ação das proteases sobre a caseína. A atividade proteolítica foi determinada pelo índice de revelação enzimática ( $I R E=D / d)$, em que $\mathrm{D}=$ diâmetro total (colônia + halo) e d = (diâmetro da colônia).

Visando à caracterização genotípica dos isolados bacterianos utilizou-se a técnica do PCR-RAPD, onde inicialmente procedeu-se à extração de DNA genômico das bactérias pelo método CTAB de Doyle \& Doyle (1990) com adaptações. Para isto foram transferidos $20 \mathrm{mg}$ de células, previamente centrifugadas e lavadas com água estéril, de cada isolado para tubos Eppendorf de 1,5 mL contendo $500 \mu \mathrm{L}$ de tampão CTAB(CTAB2\%; $\mathrm{NaCl}$ 1,4 M; Tris-HCL 100 mM,pH 8,0 ; EDTA $20 \mathrm{mM}$ ) e levados para banho seco a $65^{\circ} \mathrm{C}$ por 30 minutos, sendo homogeneizado em vortex ${ }^{\circledR}$ a cada 10 minutos. Em seguida acrescentou-se clorofórmio:álcool isoamílico (24:1) na mesma proporção do CTAB e homogeneizou-se por inversão. As amostras foram então centrifugadas a $12.000 \mathrm{rpm}$ por 10 minutos e o sobrenadante foi retirado e transferido para outros tubos Eppendorf, acrescentando-se $240 \mu \mathrm{L}$ de isopropanol absoluto a $-20^{\circ} \mathrm{C}$ homogeneizando por inversão, sendo mantido nesta temperatura por 24 horas. Posteriormente o material foi centrifugado a $14000 \mathrm{rpm}$ por 5 minutos, o sobrenadante desta vez foi descartado e o precipitado (pellet de DNA) lavado com $500 \mu \mathrm{L}$ de etanol $70 \%$ a $8{ }^{\circ} \mathrm{C}$, centrifugando-se novamente a $5.000 \mathrm{rpm}$ por 5 minutos. $\mathrm{O}$ etanol foi descartado e o precipitado seco em fluxo de ar à temperatura ambiente. O DNA foi hidratado em $100 \mu \mathrm{L}$ de tampão TE e levado a banho seco por 30 minutos a $55^{\circ} \mathrm{C}$. O DNA genômico foi, então, submetido à quantificação pela técnica de eletroforese em gel de agarose a 1.0\% utilizando-se o tampão de corrida TBE $1 / 2 \mathrm{X}$, embebido em brometo de 
etídeo e visualizados em câmara com iluminação ultravioleta (câmara CCD Alpha-Inmotech).

O DNA genômico obtido foi então amplificado pelo método de RAPD (Williams et al., 1990) utilizando-se 11 primers decâmeros de combinações arbitrarias com as seguintes seqüências 5'-3': A1 (CAGGCCCTTC), A2 (TGCCGAGCTG); A11 (CAATCGCCGT), A18 (AGGTGACCGT),C2(GTGAGGCGTC),C5(GATGACCGCC), C7 (GTCCCGACGA), C8 (TGGACCGGTG), C11 (AAAGCTCGTC), C13 (AAGCCTCGTC) e C20 (ACTTCGCCAC) previamente selecionados, da OPERON Technologies Inc. O volume de reação foi de $25 \mu \mathrm{L}$, contendo $18,4 \mu \mathrm{L}$ de Água Mili Q; $2,5 \mu \mathrm{L}$ de Tampão (10 X); 2 mM de $\mathrm{MgCl}_{2} ; 200 \mu \mathrm{M}$ de DNTP; 10 pmols do primer (oligonucleotídeo); $1 \mathrm{U}$ de Taq DNA polimerase; e 1,0 $\mu \mathrm{L}$ de DNA (100 ng). As reações de RAPD ocorreram em termociclador MJ - PTC 100 programado para desnaturação inicial de $94^{\circ} \mathrm{C}$ por 5 minutos, com 48 ciclos constituídos por: desnaturação a $92^{\circ} \mathrm{C}$ por 30 segundos; anelamento a $37^{\circ} \mathrm{C}$ por 1 minuto e 30 segundos a $72{ }^{\circ} \mathrm{C}$ para extensão final. Os produtos da amplificação foram submetidos a eletroforese em gel de agarose a $1,2 \%$, corado com brometo de etídeo utilizando o tampão de corrida TBE $1 / 2 \mathrm{X}$ com marcador Ladder Invitrogen 100pb. O gel foi visualizado em câmara com iluminação ultravioleta (câmara CCD Alpha-Inmotech) sendo as imagens capturadas pelo software ChemiImager ${ }^{\circledR}$. Foi extraído também, pelo método Doyle \& Doyle (1990), com posterior amplificação por RAPD, o DNA de isolados de Xanthomonas campestris, Aspergillus niger e duas estirpes de Bacillus subtilis AP-3 e A3-5 (Araujo et al., 2005). As bandas de DNA foram analisadas quanto à presença e ausência em cada isolado. A matriz de similaridade foi construída de acordo com o programa NTSYS 2.0 pelo agrupamento UPGMA.

Como avaliação final dos isolados bacterianos, foi conduzido um experimento em casa-de-vegetação durante 180 dias objetivando-se avaliar os mesmos como inoculantes paraBrachiariabrizantha(Hochstex A. Rich.) Stapf.cv. Marandú. Utilizou-se um argissolo vermelho distroférrico (EMBRAPA, 1999) coletado na camada $0-20 \mathrm{~cm}$ de profundidade, seco ao ar e passado em peneira $(2 \mathrm{~mm})$. Posteriormente, procederam-se ao enchimento dos vasos de $4 \mathrm{dm}^{3} \mathrm{e}$ à coleta de amostra para caracterização de atributos químicos (Raij et al.,2001), encontrando-se os seguintes valores: $\mathrm{pH}\left(\mathrm{CaCl}_{2} 1 \mathrm{molL}^{-1}\right) 6,0$; $6 \mathrm{~g} \mathrm{dm}^{-3}$ de M.O.; $38 \mathrm{mg} \mathrm{dm}^{-3} \mathrm{de} \mathrm{P}_{\text {resina }} ; 3,6 \mathrm{mmol}_{\mathrm{c}} \mathrm{dm}^{-3} \mathrm{de} \mathrm{K}$; $24 \mathrm{mmol}_{\mathrm{c}} \mathrm{dm}^{-3} \mathrm{de} \mathrm{Ca} ; 8 \mathrm{mmol}_{\mathrm{c}} \mathrm{dm}^{-3} \mathrm{de} \mathrm{Mg} ; 36$ mmol $_{\mathrm{c}} \mathrm{dm}^{-3} \mathrm{de}$ $\mathrm{SB} ; 51 \mathrm{mmol}_{\mathrm{c}} \mathrm{dm}^{-3} \mathrm{de}$ CTC; $70 \%$ de saturação por bases. A capacidade de campo do solo desestruturado foi determinada no aparelho extrator de Richards a-0,03 MPa como $175 \mathrm{~g} \mathrm{~kg}^{-1}$.Os vasos foram irrigados diariamente para manter o teor de umidade próximo à capacidade de campo, calculada anteriormente utilizando-se do método gravimétrico.

Para inoculação das sementes de braquiária, foi utilizado 1,0 mL de suspensão líquida de cada isolado bacteriano em $10 \mathrm{~g}$ de sementes. Para obtenção do inóculo, os isolados foram multiplicados em tubos com meio de cultura sólido durante sete dias e acrescidos de $5 \mathrm{~mL}$ de água estéril no interior dos tubos com posterior raspagem das bactérias. Os inóculos de cada isolado foram padronizados utilizando-se espectrofotometria com a finalidade de manter a concentração aproximada de $1,0.10^{8}$ bactérias $\mathrm{mL}^{-1}$ para cada isolado (Romeiro, 2007). Para semeadura, utilizaram-se dez sementes por vaso. Após a emergência das plantas, foi realizado o desbaste deixando-se duas plantas por vaso. O delineamento experimental empregado foi o inteiramente casualizado com medidas repetidas no tempo, com oito tratamentos (sete isolados e uma testemunha), três períodos de cortes e quatro repetições.

O período experimental iniciou-se com o corte de uniformização, aos 42 dias após a semeadura, deixando-se as plantas com altura aproximada de $10 \mathrm{~cm}$. Após isto foram efetuados três cortes, a $10 \mathrm{~cm}$ de altura da superfície do solo, a cada 45 dias, para avaliar o número de perfilhos por vaso, a área foliar, em aparelho medidor de área foliar portátil modelo LI-3000A (LI-COR,USA), matéria seca da parte aérea, por secagem em estufa $\left(65^{\circ} \mathrm{C}\right)$ com circulação de ar até massa constante e a razão da área foliar (RAF), obtida pela divisão da área foliar pela massa seca da parte aérea.

Os dados foram submetidos à análise de variância e ao teste F pelo Mixed Procedure (PROC MIXED) do pacote estatístico SAS (versão 8.0). Para a escolha da matriz de variância e covariância, utilizou-se o critério de informação de Akaike. As médias dos tratamentos foram comparadas pelo teste de Tukey. As variáveis bioquímicas obtidas com isolados bacterianas foram correlacionadas com todas as variáveis fitotécnicas utilizando-se a análise de correlação de Pearson. Adotou-se $\alpha=0,05$.

\section{Resultados e Discussão}

Apenas o isolado 1B não propiciou antagonismo a uma espécie de fungo fitopatogênico, enquanto o isolado 6B apresentou antagonismo às duas espécies avaliadas (Tabela 1). Os isolados bacterianos $1 \mathrm{~A} \mathrm{e} 3 \mathrm{~A}$ foram os que apresentaram maior potencial quanto à produção de ácido-indol-acético (AIA) e, de acordo com o critério estabelecido por Barazani \& Friedman (1999), podem ser considerados eficientes produtores de auxinas. $\mathrm{O}$ isolado $6 \mathrm{~A}$ foi o que apresentou maior potencial na produção de fosfatases, enquanto o $1 \mathrm{~B}$ proporcionou maior produção de proteases. 
Tabela 1 - Comportamento de sete isolados de Bacillus sp. em diferentes atributos bioquímicos de interesse agrícola efetivados em laboratório

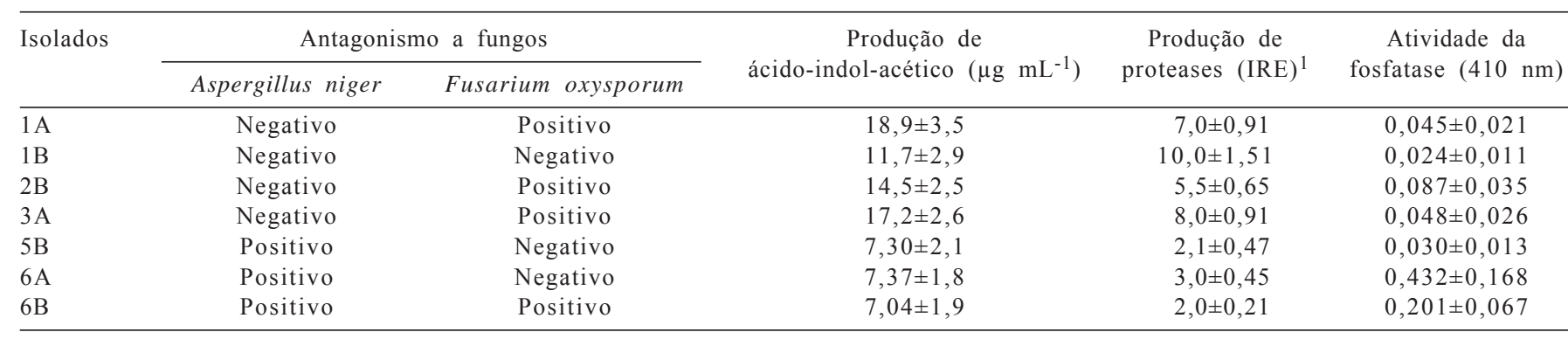

${ }^{1}$ IRE $=$ índice de relação enzimática.

A análise de PCR-RAPD revelou, pelos coeficientes de similaridade próximos a $30 \%$, encontrados nos diferentes agrupamentos, considerável heterogeneidade genética entre os isolados bacterianos (Figura 1). Apesar de a análise de PCR-RAPD não ser muito útil para relacionamento ou identificação de espécies, pode servir para mostrar, pelo polimorfismo encontrado, a alta ou baixa heterogeneidade genética entre os isolados, segundo Matarante et al. (2004). Esses mesmos autores, com a utilização do PCR-RAPD, encontraram coeficientes de similaridade que variaram de 12 a $99 \%$ dentro do gênero Bacillus.

O polimorfismo de RAPD depende da configuração de primers utilizados e de seus produtos de amplificação. Quanto maior for esse número, maiores serão as chances de se detectar polimorfismo e consequentemente os resultados serão mais confiáveis (Olive \& Bean, 1999). Dos 11 primers utilizados neste estudo, dois (A1 e A11) se destacaram como de maior

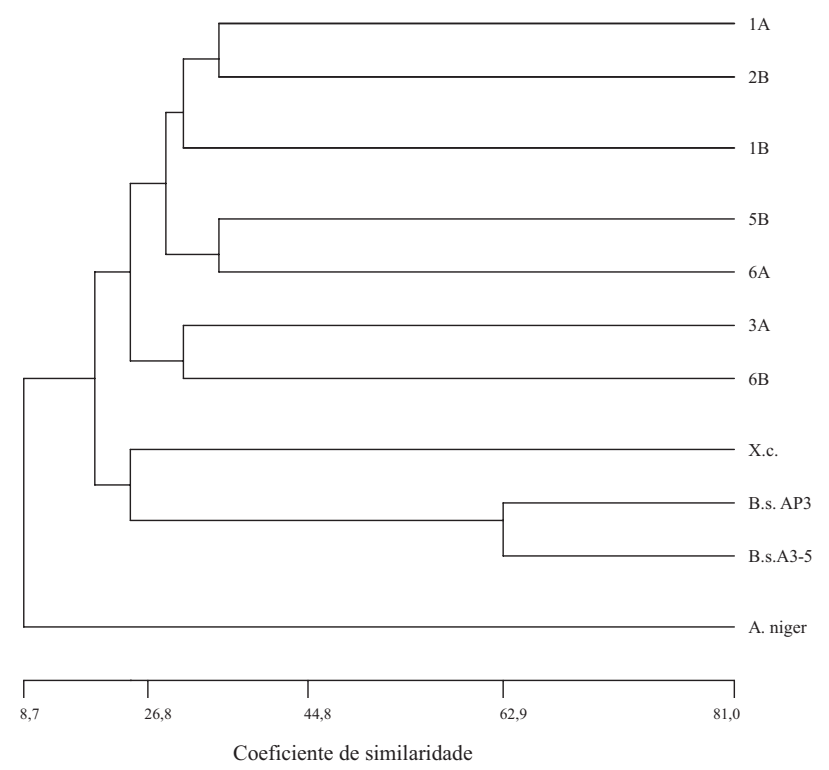

Figura 1 - Relacionamento genético entre os sete isolados de Bacillus (1A, 1B, 2B, 3A, 5B, 6A e 6B) baseado na análise de PCR-RAPD e coeficiente de similaridade de Jacard. B.s. = Bacillus subtilis; X.c. $=$ Xanthomonas campestris e A. niger $=$ Aspergillus niger . amplificação de bandas e podem ser úteis nas análises de relacionamento genético de Bacillus.

No experimento com plantas, houve efeito significativo $(\mathrm{P}<0,01)$ para o período de corte em todas as variáveis testadas, entretanto não ocorreram interações entre os períodos de corte e os tratamentos com isolados bacterianos. Houve significância $(\mathrm{P}<0,05)$ para isolados bacterianos na comparação efetuada dentro das médias marginais nas variáveis: massa seca da parte aérea, perfilhamento e área foliar das plantas (Tabelas 2 e 3 ).

A inoculação do isolado de Bacillus $6 \mathrm{~A}$ proporcionou maior produção de massa seca na parte aérea, na média dos três cortes efetuados (Tabela 2). Este resultado comprova o potencial de promoção de crescimento de plantas por Bacillus sp. já encontrado em vários estudos com diferentes culturas (Araujo \& Guerreiro, 2010; Figueiredo et al., 2010; Araujo, 2008; Coelho et al., 2007; Malik et al., 1997).

O perfilhamento da planta, na média final, aumentou com inoculação dos isolados $1 \mathrm{~A}$ e $2 \mathrm{~B}$ comparando-se à testemunha (Tabela 2). Esses isolados também se destacaram como produtores de auxinas (Tabela 1). De acordo com Gomide (1988), o perfilhamento é diretamente influenciado pelas auxinas, como também Taiz \& Zeiger (2004) relataram que as auxinas são os únicos fitorreguladores que aumentam a formação de primórdios radiculares. Incrementos no perfilhamento também já foram encontrados em outras gramíneas após inoculação com Bacillus spp. (Afzal et al., 2005; Latake et al., 2009)

Apenas o isolado 2B proporcionou incremento de área foliar na gramínea quando comparado à testemunha (Tabela 3 ). Contudo, a razão de área foliar (RAF) não foi alterada significativamente por nenhum tratamento. Kelemu et al.(2011) avaliando a inoculação de $B$. brizantha com três estirpes bacterianas, originalmente isoladas de um híbrido de Brachiaria, também encontraram aumento de cerca de $50 \%$ na área foliar das plantas.

Os isolados de Bacillus sp. 1A, 2B e 6A destacaram-se como promotores de crescimento de Brachiaria brizantha. 
Pela aplicação do teste de correlação de Pearson entre as diferentes variáveis analisadas (Tabela 4), verificou-se que a produção de fosfatase e AIA proporcionada pelos sete isolados bacterianos avaliados in vitro apresentou maior correlação com a produção média de massa seca nas plantas $(\mathrm{r}=0,61, \mathrm{P}<0,05)$ e com a razão deárea foliar $(\mathrm{r}=0,65, \mathrm{P}<0,05)$, respectivamente. Em estudo de bioprospecção de Bacillus sp. na cultura do milho, Araujo \& Guerreiro (2010) concluíram que a maior produção de AIA não foi uma característica principal dos melhores isolados bacterianos que promoveram o crescimento do milho. Entretanto, Khalid et al. (2004) relataram correlação positiva entre a produção de auxina in vitro e o aumento do crescimento das plantas após a inoculação das rizobactérias. Com relação à atividade de solubilização de fósforo encontrada em isolados bacterianos e a correlação com parâmetros fitotécnicos, Idris et al. (2009)

Tabela 2 - Produção de massa seca na parte aérea e perfilhamento de Brachiaria brizantha em função da inoculação de sementes com diferentes isolados de Bacillus sp. nos três cortes efetuados

\begin{tabular}{lcccc}
\hline \multirow{2}{*}{ Tratamentos } & 1o Corte & 20 Corte & 30 Corte & Média \\
\cline { 2 - 5 } & \multicolumn{4}{c}{ Produção de massa seca (g por vaso) } \\
\cline { 2 - 5 } Testemunha & 3,05 & 1,60 & 1,63 & $2,09 \mathrm{~b}$ \\
Isolado 1A & 2,77 & 1,38 & 1,51 & $1,87 \mathrm{~b}$ \\
Isolado 1B & 3,23 & 1,62 & 1,56 & $2,14 \mathrm{ab}$ \\
Isolado 2B & 3,50 & 1,89 & 1,57 & $2,32 \mathrm{ab}$ \\
Isolado 3A & 3,47 & 1,53 & 1,51 & $2,16 \mathrm{ab}$ \\
Isolado 5B & 2,82 & 1,53 & 1,37 & $1,91 \mathrm{ab}$ \\
Isolado 6A & 3,46 & 2,03 & 1,70 & $2,39 \mathrm{a}$ \\
Isolado 6B & 2,80 & 1,67 & 1,70 & $2,05 \mathrm{~b}$ \\
Média & $3,13 \mathrm{~A}$ & $1,65 \mathrm{~B}$ & $1,56 \mathrm{~B}$ & \\
CV (\%) & 11,6 & 12,2 & 9,7 & \\
& & & & \\
& & & & \\
Testemunha & 5,5 & 7,0 & 8,0 & $6,8 \mathrm{~b}$ \\
Isolado 1A & 5,3 & 9,5 & 9,5 & $8,1 \mathrm{a}$ \\
Isolado 1B & 6,0 & 8,3 & 7,8 & $7,3 \mathrm{ab}$ \\
Isolado 2B & 5,5 & 8,8 & 10,0 & $8,1 \mathrm{a}$ \\
Isolado 3A & 4,5 & 7,3 & 7,3 & $6,3 \mathrm{~b}$ \\
Isolado 5B & 4,3 & 7,8 & 7,3 & $6,4 \mathrm{~b}$ \\
Isolado 6A & 5,5 & 9,5 & 8,0 & $7,7 \mathrm{ab}$ \\
Isolado 6B & 5,0 & 8,3 & 8,3 & $7,2 \mathrm{ab}$ \\
Média & $5,2 \mathrm{~B}$ & $8,3 \mathrm{~A}$ & $8,2 \mathrm{~A}$ & \\
CV (\%) & 15,6 & 17,1 & 19,7 & \\
\hline
\end{tabular}

Médias seguidas de mesma letra minúscula na coluna e maiúscula na linha não diferem $(\mathrm{P}<0,05)$ pelo teste Tukey.

$\mathrm{CV}=$ coeficiente de variação. encontraram correlação significativa apenas com massa seca da raiz em sorgo.

Vários estudos tem sugerido que o modo de ação do antagonismo a fungos está relacionado à promoção de crescimento de plantas (Araujo et al., 2005; Idris et al., 2009; Bettiol, 1995; Romeiro, 2007; Vassilev etal.,2006). Neste estudo, todos os isolados bacterianos foram antagônicos a pelo menos uma espécie de fungo avaliado (Tabela 1). Apenas um isolado bacteriano (6B) foi antagônico às duas espécies de fungos, porém não proporcionou ganhos no crescimento de $B$. brizantha quando inoculado previamente nas sementes desta espécie.

O protocolo de bioprospecção utilizado neste trabalho propiciou o isolamento de Bacillus spp. promissores para uso na inoculação de sementes de Brachiaria. A correlação significativa encontrada entre a presença dos isolados produtores de fosfatases e AIA e o aumento no crescimento

Tabela 3 - Produção e razão de área foliar (RAF) em Brachiaria brizantha em função da inoculação de sementes com diferentes isolados de Bacillus sp. avaliada em três cortes

\begin{tabular}{|c|c|c|c|c|}
\hline Tratamentos & 1ㅇ Corte & 2o Corte & 3 o Corte & Média \\
\hline & \multicolumn{4}{|c|}{-Área foliar $\left(\mathrm{cm}^{2}\right.$ por vaso $)$} \\
\hline Testemunha & 433 & 302 & 205 & $313 b$ \\
\hline Isolado 1A & 389 & 258 & 240 & $296 b$ \\
\hline Isolado $1 \mathrm{~B}$ & 462 & 286 & 241 & $330 \mathrm{ab}$ \\
\hline Isolado 2B & 453 & 330 & 261 & $348 \mathrm{a}$ \\
\hline Isolado $3 \mathrm{~A}$ & 483 & 273 & 227 & $328 \mathrm{ab}$ \\
\hline Isolado 5B & 366 & 259 & 219 & $281 \mathrm{~b}$ \\
\hline Isolado 6A & 446 & 324 & 233 & $335 \mathrm{ab}$ \\
\hline Isolado 6B & 381 & 304 & 238 & $308 b$ \\
\hline Média & $426 \mathrm{~A}$ & $292 B$ & $233 \mathrm{C}$ & \\
\hline CV (\%) & 17,1 & 19,8 & 12,9 & \\
\hline
\end{tabular}

— Razão de área foliar $\left(\mathrm{cm}^{2} \mathrm{~g}^{-1}\right)$

\begin{tabular}{lcccc} 
Testemunha & 143 & 206 & 126 & 159 \\
Isolado 1A & 140 & 199 & 159 & 166 \\
Isolado 1B & 144 & 178 & 155 & 159 \\
Isolado 2B & 131 & 177 & 166 & 158 \\
Isolado 3A & 142 & 183 & 150 & 159 \\
Isolado 5B & 130 & 171 & 160 & 154 \\
Isolado 6A & 129 & 163 & 138 & 143 \\
Isolado 6B & 137 & 201 & 142 & 160 \\
Média & $137 \mathrm{~B}$ & $184 \mathrm{~A}$ & $148 \mathrm{~B}$ & \\
CV (\%) & 18,2 & 17,4 & 20,2 & \\
\hline
\end{tabular}

Médias seguidas de mesma letra minúscula na coluna e maiúscula na linha não diferem $(\mathrm{P}<0,05)$ pelo teste Tukey.

$\mathrm{CV}=$ coeficiente de variação.

Tabela 4 - Correlação de Pearson (r) entre variáveis bioquímicas produzidas pelos isolados bacterianos e fitotécnicas em plantas de Brachiaria brizantha inoculadas previamente com os isolados

\begin{tabular}{lccc}
\hline Variável & Produção de massa seca & Perfilhamento & Área foliar \\
\hline Produção de auxina & $-0,16$ & 0,23 & 0,16 \\
Produção de proteases & 0,027 & 0,08 & $0,65 *$ \\
Atividade de fosfatases & $0,60 *$ & 0,27 & 0,46 \\
\hline
\end{tabular}

*Significativo $(\mathrm{P}<0,05)$. 
das plantas sugere que estes critérios podem ser utilizados em outros programas de seleção. Além disso, o critério do antagonismo a fungos pode também ser útil na seleção das rizobactérias. Por outro lado, a produção de proteases nos isolados não se configurou como mecanismo importante para avaliar o desempenho das bactérias. Estudos adicionais podem ser conduzidos para elucidar a participação dos isolados bacterianos em outros modos de ação relacionados à promoção de crescimento das plantas.

\section{Conclusões}

Existem bactérias na rizosfera de Brachiaria que são caracterizadas como Bacillus sp. e podem promover o crescimento das plantas quando inoculadas previamente nas sementes. A avaliação de produção de auxinas e fosfatases mostra-se relevante para os protocolos de seleção dos isolados de Bacillus sp. como promotores de crescimento de Brachiaria brizantha.

\section{Referências}

AFZAL, A.; ASHRAF, M.; SAEED, A.A. et al. Effect of phosphate solubilizing microorganisms on phosphorus uptake, yield and yield traits of wheat (Triticum aestivum L.) in rainfed area. International Journal of Agriculture and Biology, v.7, p.207-209, 2005.

ARAUJO, F.F. Inoculação de sementes com Bacillus subtilis, formulado com farinha de ostras e desenvolvimento de milho, soja e algodão. Ciência e Agrotecnologia, v.32, p.456-462, 2008.

ARAUJO, F.F.; GUERREIRO, R.T. Biopropspecção de isolados de Bacillus promotores de crescimento de milho cultivado em solo autoclavado e natural. Ciência e Agrotecnologia, v.34, p.837-844, 2010.

ARAUJO, F.F.; HENNING, A.A.; HUNGRIA, M. Phytohormones and antibiotics produced by Bacillus subtilis and their effects on seed pathogenic fungi and on soybean root development. World Journal of Microbiology and Biotechnology, v.21, p.1639-1645, 2005.

BANZATO, D.A; KRONKA, S.N. Experimentação agrícola. 2.ed. Jaboticabal, Funep, 1992. 247p.

BARAZANI, O.; FRIEDMAN, J. Is IAA the major root growth factor secreted from plant-growth-mediating bacteria? Journal of Chemical Ecology, v.25, p.2397-2406, 1999.

BENIZRI, E.; BAUDOIN, E.; GUKERT, A. Root colonization by inoculated plant growth-promoting rhizobacteria. Biocontrol Science and Technology, v.11, p.557-574, 2001

BETTIOL, W. Isolamento seletivo de Bacillus. In: MELO, I.S.; SANHUEZA, R.M.V. (Coords.) Métodos de seleção de microrganismos antagônicos a fitopatógenos. Jaguariúna: Embrapa-CNPMA, 1995. p.35-36.

BUCHANAN, R.E.; GIBBONS, N.G. Bergey's manual of determinative bacteriology. 8.ed. Baltimore: The Willians \& Wilkens, 1975. 1268p.

COELHO, L.F.; FREITAS, S.S.; MELO, A.M.T. et al. Interação de bactérias fluorescentes do gênero Pseudomonas e de Bacillus spp. com a rizosfera de diferentes plantas. Revista Brasileira de Ciência do Solo, v.31, p.1413-1420, 2007.

DOYLE J.J.; DOYLE J.L. A RAPD DNA isolation procedure for small quantities of fresh leaf tissue. Phytochemical Bulletin, v.19, p.11-15, 1990.
EHMANN, A. The van urk - salkowski reagent- a sensitive and specific chromogenic reagent for silica gel thin-layer chromatographic detection and identification of indole derivates. Journal of Chromatography, v.132, p.267-276, 1977.

EMPRESA BRASILEIRA DE PESQUISA AGROPECUÁRIA EMBRAPA. Sistema brasileiro de classificação de solos. Rio de Janeiro: Centro Nacional de Pesquisa de Solos, 1999. 171p.

FIGUEIREDO, M.V.B.; SELDIN, L.; ARAUJO, F.F. et al. Plant growth promoting rhizobacteria: fundamentals and applications In: MAHESHWARI, D.K. (Ed.) Plant growth and health promoting bacteria.1.ed. Berlin: Springer-Verlag, 2010. v.18, p.45-68.

GOMES JÚNIOR, P.; PAULINO, M.F.; DETMANN, E. et al. Desempenho de novilhos mestiços na fase de crescimento suplementados durante a época seca. Revista Brasileira de Zootecnia, v.31, p.139-147, 2002

GOMIDE, J.A. Fisiologia das plantas forrageiras e manejo das pastagens. Informe Agropecuário, v.88, p.11-18, 1988

IDRIS, A.; LABUSCHAGNE, N.; KORSTEN, L. Efficacy of rhizobacteria for growth promotion in sorghum under greenhouse conditions and selected modes of action studies. Journal of Agricultural Science, v.147, p.17-30, 2009.

ITZIGSOHN, R.; BURDMAN, S.; OKON, Y. et al. Plant-growth promotion in natural pastures by inoculation with Azospirillum brasilense under suboptimal growth conditions. Arid Soil Research, v.13, p.151-158, 2000.

MALIK, K.A.; RAKHSHANDA, B.; MEHNAZ, S. et al. Association of nitrogen-fixing plant-growth promoting rhizobacteria (PGPR) with kallar grass and rice. Plant Soil, v.194, p.37-44, 1997.

MATARANTE, A.; BARUZZI, F.; COCCONCELLI, P.S. et al. Genotyping and toxigenic potential of Bacillus subtilis and Bacillus pumilus strains occurring in Industrial and artisanal cured sausages. Applied Environmental Microbiology, v.70, p.5168-5176, 2004

OLIVE, D.M.; BEAN, P. Principles and applications of methods for DNA-based typing of microbial organism. Journal of Clinical Microbiology, v.37, p.661-1669, 1999.

KELEMU, S.; FORY, P.; ZULETA, C. et al. Detecting bacterial endophytes in tropical grasses of the Brachiaria genus and determining their role in improving plant growth. African Journal of Biotechnology, v.10, p.965-976, 2011

KHALID, A.; ARSHAD, M.; ZAHIR, Z.A. Screening plant growthpromoting rhizobacteria for improving growth and yield of wheat Journal of Applied Microbiology, v.96, p.473-480, 2004.

LATAKE, S.B.; SHINDE, D.B.; BHOSALE, D.M. Effect of inoculation of beneficial microorganisms on growth and yield of pearl millet. Indian Journal of Agriculture Research, v.43, p.61-64, 2009.

RADWAN, T.E.E.; MOHAMED, Z.K.; REIS, V.M. Aeração e adição de sais na produção de ácido indol acético por bactérias diazotróficas. Pesquisa Agropecuária Brasileira, v.40, p.997-1004, 2005.

RAIJ, B. van; ANDRADE, J.C.; CANTARELLA, H. et al. Análise química para avaliação da fertilidade de solos tropicais. Campinas: Instituto Agronômico, 2001. 284p.

ROMEIRO, R.S. Controle biológico de doenças de plantas: procedimentos. Viçosa, MG: UFV, 2007. 172p.

SKONIESKI, F.R.; VIEGAS, J.; BERMUDES, R.F. et al. Composição botânica e estrutural e valor nutricional de pastagens de azevém consorciadas. Revista Brasileira de Zootecnia, v.40, p.550-556, 2011.

TAIZ, L.; ZEIGER, E. Fisiologia vegetal. 3.ed. Porto Alegre: Artmed, 2004. 722p

THIAGO, P.V.; SILVA, R.J. Atividade proteolítica de isolados de Metarhizium anisopliae sobre substratos cuticulares e não cuticulares. Ciencia Rural, v.37, p.26-30, 2007.

VASSILEV, N.; VASSILEVA, M.; NIKOLAEVA, I. Simultaneous P-solubilizing and biocontrol activity of microorganisms: potentials and future trends. Applied Microbiology and Biotechnology, v.71, p.137-144, 2006.

WILLIAMS, J.G.K.; KUBELIK, A.R.; LIVAK, K.J. et al. DNA polymorphism amplified by arbitrary primers are useful as genetic markers. Nucleic Acids Research, v.18, p.6531-6535, 1990. 